IZA DP No. 7018

The Decline of Professional Football in Italy

Tito Boeri

Battista Severgnini

November 2012 


\title{
The Decline of Professional Football in Italy
}

\author{
Tito Boeri \\ IGIER - Bocconi University, \\ CEPR and IZA \\ Battista Severgnini \\ Copenhagen Business School
}

\section{Discussion Paper No. 7018 \\ November 2012}

\author{
IZA \\ P.O. Box 7240 \\ 53072 Bonn \\ Germany \\ Phone: +49-228-3894-0 \\ Fax: +49-228-3894-180 \\ E-mail: iza@iza.org
}

Any opinions expressed here are those of the author(s) and not those of IZA. Research published in this series may include views on policy, but the institute itself takes no institutional policy positions. The IZA research network is committed to the IZA Guiding Principles of Research Integrity.

The Institute for the Study of Labor (IZA) in Bonn is a local and virtual international research center and a place of communication between science, politics and business. IZA is an independent nonprofit organization supported by Deutsche Post Foundation. The center is associated with the University of Bonn and offers a stimulating research environment through its international network, workshops and conferences, data service, project support, research visits and doctoral program. IZA engages in (i) original and internationally competitive research in all fields of labor economics, (ii) development of policy concepts, and (iii) dissemination of research results and concepts to the interested public.

IZA Discussion Papers often represent preliminary work and are circulated to encourage discussion. Citation of such a paper should account for its provisional character. A revised version may be available directly from the author. 
IZA Discussion Paper No. 7018

November 2012

\section{ABSTRACT}

\section{The Decline of Professional Football in Italy*}

There are three main critical areas in the Italian football industry. First, we find that the revenues of teams playing in Serie A are low and highly concentrated on TV rights, hence vulnerable to changing conditions in the mass media industry. Second, we document that there has been an exponential growth of players' salaries, which has been historically driving up the total costs up to unsustainable levels. The third problem relates to a lack of credibility of the competition, due to a long list of scandals and its potential effects on revenues. In particular, the 2006 investigation on match rigging, and the new episodes on betting scandals in 2009 and 2010, have depressed the total revenues of all teams not only of those directly involved in match fixing. There can also be second round effects via a deterioration of the quality of games, which may also reduce revenues of the clubs. Possible ways out of these problems are discussed in the last section.

JEL Classification: J24, J44

Keywords: $\quad$ superstar effects, match fixing, career concerns

Corresponding author:

Tito Boeri

Department of Economics

Università Bocconi

Via Roentgen 1

20136 Milano

Italy

E-mail: tito.boeri@unibocconi.it 


\section{Introduction}

From being the best football tournament in the world, the Italian First Division (also known as Serie $A)$ is getting more and more marginal in the global arena. There a few star players left, and no superstar as they were poached by teams playing in the Premier League, the Liga, the French first division or other remote championships where there are club Presidents who can afford them. From having 4 teams qualifying to the Champions League, Italian football may soon have only 2 teams involved in the most important tournament at the Continental level. Every year, Serie A loses about 5 per cent of stadium spectators with respect to the previous season. More importantly, financial conditions of Serie A teams are getting worse and worse. In the 2010-11 football season, the total debt of Serie A increased to 2.6 billion, roughly $1 / 6$ of a point of Italian GDP, a 60 per cent increase with respect to the 2006-7 season. The debt to asset ratio, an indicator of (in)sustainability, increased even more, as the drain of top players and sales of real estate owned by the teams reduced total assets by some 200 millions. The bad financial conditions span beyond Serie A. Only 19 out of 107 professional clubs realized net profits in 2010-11. Although football is still the most popular and the most practicised sport in Italy, and it raises much more interest (and passion) than anywhere else in Europe, revenues of clubs are low by international comparison and are stagnant or even declining over time.

In this chapter we try to unveil the reasons behind the decline of Italian professional football and the paradox of a strong popular support which is not cashed in by the clubs. We do so by providing an overview of the evolution of the financial conditions of professional football in the last ten years. Particular attention is devoted to the level and composition of costs and revenues in the Serie A. Based on updated accounting data, we document that Italian professional football teams are experiencing a rise of their outstanding debt and face a broader sustainability issue. Clubs are clearly aware of these problems and recently tried to reduce their operating losses mainly by cutting expenditure, notably compensation to players. Not enough attention has been devoted so far to restructure and expand revenues. Persistent obstacles to move in this direction may also explain why, in spite of the popularity of football in Italy, no large foreign investor so far targeted the Campionato.

This chapter, in particular, points to three main critical areas in the Italian football industry. First, we find that the revenues of teams playing in Serie A are low and highly concentrated on TV rights, hence vulnerable to changing conditions in the mass media industry. Second, we document that there has been an exponential growth of players' salaries, which has been historically driving up the total costs up to unsustainable levels. The third problem relates to a lack of credibility of the competition, due to a long list of scandals and its potential effects on revenues. In particular, the 2006 investigation on match rigging (also known as Calciopoli), and the new episodes on betting scandals in 2009 and 2010, have depressed the total revenues of all teams not only of those directly 
involved in match fixing. There can also be second round effects via a deterioration of the quality of games, which may also reduce revenues of the clubs.

The first two critical areas are quite obviously correlated. A positive association between revenues from media rights and the compensation of professional footballers is a typical by-product of the socalled superstar effect. During the last 20 years technological innovations in broadcasting created new potential markets with a number of potential participants proxying the global scale. This had the double effect of both enhancing the amount of resources offered to the different competitors in the Championship and, at the same time, it redistributed the resources among the best teams and the most famous players. The importance of media in Italian football may also have affected the frequency of corruption episodes. In the case of Calciopoli, in particular, media pressure was essential to capture by threat.

In this chapter we try as much as possible to carry out comparisons between Italy and the rest of Europe. This documents the greater degree of diversification of revenues of football teams in other countries. Elsewhere in Europe both revenues and costs are more diversified: TV rights and players' salaries take a lower share of the total budget than in Italy. At the same time, the competitive power of an increasing number of European teams is stronger than that of Serie A teams, both at the sportive and financial levels.

In order to understand the reason for these discrepancies, we investigate the Italian institutional environment and the ownership structure in Serie A, concluding that new frameworks and rules in the governance should be pursued. Moreover, we find that the Italian soccer teams' soft budget constraint could also have several negative spillovers on the sportive results and the quality of the teams in the long run. The Italian Serie A is losing competitiveness compared not only to the Premier League in England and the Liga in Spain, but also relative to somewhat smaller tournaments like the Bundesliga and the French Championship. The first symptoms of this decline are in the decisions of A.C. Milan and Inter to sell top star players like Zlatan Ibrahimović, Thiago Silva and Samuel Eto'o in order to alleviate their own budget deficits.

In the last section of the chapter, we discuss ways out of these problems. A change in the governance structure of football, both at the level of individual teams and of the federal structures is warranted, which should provide more representation to broader interests than those of the owners of clubs. Antitrust authorities should also keep an eye on the interconnections between ownership of clubs and media power, as it proved to be a factor in the Calciopoli scandal altering the competitive balance by affecting the performance of the referees. There may be also grounds to conclude, alongside the British Monopolies and Merger Commission (in the case of the planned takeover of Manchester United by BSkyB in 1999) that these arrangements could damage competition among broadcasters. Financial fair play introduced by (UEFA 2010) is a necessary but not sufficient condition to restore the sustainability of Italian football. Budgets of clubs should be certified and transactions among clubs should be closely monitored as they have been widely used in the past to alter the asset position of clubs. 
All this is likely to involve a further reduction of the number of professional clubs operating in Italy, which are indeed far too many, taking into account of the size of the industry and the fixed costs involved in the running of a team. Due to the popularity of football in Italy, a case can also be made for delegating authority to supranational bodies, that are in a better position to enforce the rules of law than institutions subject to the "too popular to fail" syndrome. European integration could be in terms of heightened attention on the redistribution of media rights, new rules in the governance of the teams, and better control both over the financial condition of clubs and the enforcement of the rules of the game.

The remainder of this chapter is structured as follows. Section 2 provides an overview of the economic situation of Italian football and documents the widening operating losses in the last five years. Section 3 investigates the structure of revenues, disentangling gate rights and matchdays income from sponsorships and TV rights. Section 4 analyses the structure of costs, focusing in particular on compensation of players. Section 5 carries out international comparisons that are particularly useful in highlighting the specificity of the Italian case. Section 6 looks at match rigging episodes and investigates the effects of Calciopoli on attendance of sports events. Finally, Section 7 summarizes the main results of our analysis and proposes some strategies to tackle the structural problems of Italian football.

\section{An open-ended history of losses and bankruptcies}

There is little doubt that football is the most popular and the most practiced sport in Italy. About 600 thousands regular games are played every year, more than in the UK. According to the Italian Statistical Office (Istat 2005), more than 10 per cent of the Italian male population plays soccer regularly. The audience of Italian football matches is well above that of any other sport, including the Giro d'Italia. Three Italians out of four are interested in the Serie A, the national team has about 28 million supporters ${ }^{1}$ and 26 million of Italians watch regularly the games organized by UEFA.

Italy has also a longstanding tradition in football. In the New Millenium, the Italian national squad won the World Cup in 2006 and played the European finals in 2000 and 2012. Furthermore, since 2001 Italian professional teams won the UEFA Champions League 3 times, while the UEFA season country coefficient rankings (based on all the 53 European championships) for Italy ranged from the first to the sixth position.

Professional football in Italy has also economic significance strictly speaking: a recent study by PricewaterhouseCooper (AREL, PricewaterhouseCoopers and Federcalcio 2012) shows that the aggregate turnover generated by all the teams participating in professional football tournaments ${ }^{2}$

\footnotetext{
${ }^{1}$ For instance, the recent match Italy vs. Germany at the European championship was watched by more than 20 milion people.

${ }^{2}$ Italian professional football is structured into four different divisions: Serie A, Serie B, and Lega Italiana Calcio Professionistico (Lega Pro), which it is itself divided into two groups. Given the availability of data and statistics, we
} 
amounted in 2011-12 to about 2,477 million euro, some 0.15 percent of GDP or just a little bit less than the level reached by one of the most successful Italian food producers, Ferrero, which is the $50^{\text {th }}$ biggest company in the country (Mediobanca 2011). Moreover, all the professional soccer teams contribute a total of 1.3 billion euro of tax revenues.

However, any serious business analyst would be deeply alarmed by the financial conditions of Calcio. A few indicators well capture the dismal state of the Italian football industry. First of all, Italian soccer is subject to a high mortality rate. Out of 37 teams participating in Serie $A$ in the period 2001/02-2010/11, 9, that is, 25 per cent of the total, had to declare bankruptcy. ${ }^{3}$ Second, data on the level of debt and on profit and/or losses of teams are worrying. Accounting data of soccer teams, summarized in Figure 1, point to an upward trend in net losses in the last ten years, with an average of about 250 million of euros of losses per year, peaks above 300 millions in 2002/2003, 2003/2004, and 2010-2011 and a compound annual growth rate (CAGR) ${ }^{4}$ of operational losses of 7 per cent (a trend at which losses double in about 10 years).. Actually, as mentioned at the outset the total debt of Serie A clubs have been increasing at a faster speed in the last five years (+60 per cent since 2006-7) implying a compound growth rate of about 9 per cent per year.

It should also be stressed that these numbers may underestimate actual losses. As pointed out by several accounting and legal studies (e.g., (Bianchi and Corrado 2004)), it is very difficult to obtain from clubs precise measures of extraordinary items, once the losses are computed. Moreover, several news inquiries (e.g., (Malaguti 2002)) showed that soccer teams often used manipulated extraordinary profits to reduce the reported losses.

Thus, the financial condition of Italian soccer could well be even worse than documented by PricewaterhouseCooper. According to the Italian economic daily newspaper Il Sole 24 Ore (Dragoni 2012), the loss documented in the last accounting year are not completely truthful since the net profits are inflated by extraordinary items derived by capital gains of market transfers of soccer players worth some 348.5 million euro. Since most of those gains are generated among teams participating in the Italian Serie A, a more realistic estimate of the total losses of the First Division would be 648 million euros.

[Figure 1 about here]

In the following sections we will investigate the likely determinants of these huge losses of Italian football. At first we shall look at the evolution of the turnover figures and provide a decomposition of revenues of clubs. Next, we will turn to the cost side, focusing in particular on compensation of players. Finally, we will offer some tentative explanations for these trends, looking at the institutional framework and the ownership of the teams.

concentrate our analysis on the 37 teams which have participated at least once in Serie $A$ during the championship periods 2001/02 -2010/11.

${ }^{3}$ These 9 teams are, in alphabetical order, Ancona, Como, Fiorentina, Messina, Perugia, Piacenza, Torino, Treviso, and Venezia.

${ }^{4}$ The CAGR is computed as follows: CAGR=((Ending Value $) /($ Begininng value $\left.)\right)^{\wedge}((1 /($ n.of championships $)))-1$ 


\section{Stagnating Revenues: TV rights and little else}

Figure 2 takes a look at the revenue side of the budget of Serie $A$ teams, drawing on Price Watherhouse data (AREL, PricewaterhouseCoopers and Federcalcio 2012). In order to avoid the measurement problems discussed in the previous section, we do not consider extraordinary revenues related to the transfers of players across Serie A teams. Unfortunately, we cannot control for lump-sum revenues coming from other sources, such as real estate. As the balance sheet data we had access to are in nominal terms, we deflated the series using the Italian consumer price index (ISTAT 2012). Notice further that in the 2004-2005 season, the number of teams in Serie A was increased from 18 to 20 teams. Thus, in interpreting revenue and cost figures, we prefer as much as possible to concentrate on the period since 2004-5.

Aggregate turnover increased markedly between the 2006-7 and the 2007-8 Championship, mainly due to the two different facts. First, Juventus, the most popular Italian team in 2006-7 had been relegated to the Second Division (Serie B) due to its involvement in the Calciopoli scandal. Second, teams located in populated Italian cities, e.g Genoa and Napoli, were promoted to the First Division. However, in the following years revenues were stagnating, totalling about 1,5 billions both in 2007-8 and 2010-11.

Figure 2 provides also information on the structure of revenues. In particular, we decompose aggregate turnover into five components: i) sales of season tickets and tickets at the stadium in matchdays (matchday), ii) revenues from advertising and commercial activities (commercial), iii) revenues from TV and other types of media rights (broadcasting), iv) revenues from sponsorship (sponsor), and v) revenues from other sources (other).

[Figure 2 about here]

\section{Revenues from TV and other media rights}

The lion's share of revenues is represented by revenues from TV and new media rights. They are almost stable in nominal terms and represent about 56 per cent of total revenues in 2010-11, the last championship considered. Just like in other countries, broadcasting revenues became an important source of financing fot clubs after the introduction of the encryption technology and the creation of the "pay-per-view" and digital TV channels.

In Italy this new technology for soccer games was introduced for the first time in 1993 and, after several attempts of small broadcasting companies to obtain the rights for specific teams or matches, since March 2004 the satellite TV SKY Italia obtained the right for all the games played in Serie A, while the digital TVs Mediaset Premium, owned by A.C. Milan and former Italian Prime Minister Silvio Berlusconi, and the Swedish group Dahlia TV shared the rights for broadcasting the matches on the digital technology. During the 2006-2007 championship SKY Italia decided to buy the entire rights for Serie B in order to cover popular teams such as Juventus, Genoa, and Napoli. 


\section{Revenues from stadium attendance}

Revenues from attendance at the stadium are stable or declining. Most of the time, Italian stadiums are empty. In 2010 the owner of Triestina, a Second Division team, decided to close the seated area of the stadium to save money and fill those empty seats with faked cardboard fans instead. In Figure 3 we display data on the average number of spectators (which is less than 25,000 per match throughout the entire period) in Serie A. During the Championship 2010-2011, the average number of spectators in the Bundesliga was almost twice as large $(42,000)$, in the Premier League was one third larger $(34,000)$, while in the Spanish Primera Division it was 10 per cent higher than in Italy $(28,000))^{5}$ The low number of Italian supporters going to the stadium cannot be explained by the high price of the ticket or by the excess of supply of soccer events (those values are in line, if not lower, than in other European championships).

The reasons for the low attendance rates are likely to be related to several episodes of violence and hooliganism occurred in proximity, if not within, Italian stadiums and in measures introduced by the Italian government reacting to these episodes, which possibly restricted the number of supporters at the stadium. According to statistics provided by the Italian Interior Ministry (Ministero dell'Interno 2008), in the 2004/2005 championship some 272 matches of professional football were affected by episodes of violence with a total of 1,219 people injured. These episodes induced many people to watch games in front of the TV set instead of going to the stadium.

[Figure 3 about here]

In 2007, as a reaction of riots at the margin of the match Catania-Palermo, which caused the death of an Italian police officer, the Italian government decided to introduce new regulations forcing teams with low safety standard at the stadium to play without supporters of the away teams or without spectators at all. Moreover, as a result of these tougher regulations, teams now have to employ a number of private stewards to guarantee the security in the stadium during the game. Additional measures were taken in 2009, when the Interior Ministry introduced an identity card for supporters (also known as Tessera del tifoso) which is needed to attend matches which are considered potentially dangerous by the Italian police. As Figure 3 suggests, in spite of the decline in the reported number of violent episodes in recent years (Masucci and Gallo 2012), the number of spectators per match did not recover, and actually fell to 20,000 in the 2006/2007 championship.

The role played by violent activities in the fall of stadium attendance can be assessed by comparing revenues across different divisions of professional football in Italy. In the lower Divisions (Serie $B$ and Lega Pro), the number of reported violent activities is high by international standards and has not been falling over time as in Serie A (Ministero dell'Interno 2008). Figure 4 compares the structure of revenues in Serie $B$ and the two leagues of Lega Pro in the last 3 Championships. We apply the same breakdown as in Figure 2. The data are obtained residually, as the difference between total revenues of the professional football in Italy (provided by PriceWaterhouse Cooper)

\footnotetext{
${ }^{5}$ Source: http://www.european-football-statistics.co.uk/
} 
and the data reported in Figure 2 concerning only the First Division. This points to a stronger decline of the revenues related to match days in these lower divisions than in Serie A. Although commercial revenues are increasing in Serie B and Lega Pro, probably due to the investments of local enterpreneurs who concentrate the advertising of their own companies in more restricted regional areas, the structure of revenues is even more concentrated in the lower Divisions than in Serie A.

[Figure 4 about here]

This fall may also be related to corruption episodes highlighted by the Calciopoli investigation in 2006. Indeed, revenues from match attendance declined strongly for all teams involved (Babatunde, Migali and Simmons 2012). There was also a negative spillover on attendance for the other teams.

\section{Other revenues}

According to Baroncelli and Lago (Baroncelli and Lago February 2006), revenues from commercial activity are comparatively small in Italy for two main reasons. First, Italian supporters are less used to buy merchandise from their own team than their counterparts in other European countries, e.g., the UK. Furthermore, in Italy there is widespread forgery of soccer gadgets and violation of trademarks due to the presence of a large underground economy. Finally, the income derived from the sponsorships is quite stable over time since, as we are going to document in Section 5 below, often sponsorships are closely related to the ownership of the team.

\section{The specificity of the Serie A case}

How specific to Serie $A$ is this structure of revenues? Ideally one should carry out some international comparisons of balance sheet data, offering a comparable breakdown of revenues, for other professional leagues in Europe. Unfortunately, such data are not available and hence we need to concentrate only on the top European teams, drawing from (Deloitte LLP 2012).

Figure 5 reports the level and structure of revenues for the top 20 European Teams during the years 2010-2011. Differences are quite striking. TV and other media rights take a larger share of total revenues in Italian teams than in the other top teams, while matchday revenues in Italy are negligible by international standards. The non-Italian teams, notably the Spanish and the German ones, seem to be more diversified in the composition of revenues. The low level of matchday and commercial revenues of Italian teams suggests that they have some potential for increasing total revenues.

[Figure 5 about here]

\section{The Unbearable Heaviness of Wage Costs.}


Figure 6 displays a measure of the total costs of Serie A teams, as obtained from accounting data, by adding up material costs, costs of employees, depreciation, and interest rates. The same caveats related to the number of teams that were made when discussing revenue data, apply here.

[Figure 6 about here]

Total costs increased by almost 55 per cent from 2004-5 to 2010-11. Notice further than the lion's share of costs is represented by employment costs: they account for more than 90 per cent of total costs since 2004/2005.

Why are employment costs so important? Economic theory, notably the theory of superstars (Rosen 1981) and (Rosen and Sanderson, Labour Markets in Professional Sports 2001), is particularly useful in this respect. The superstar effect arises from a combination of preferences of the winnerstake-all type (rewarding excellence and penalizing mediocrity) and technological advances increasing the potential size of markets. The combination of these two factors gives a very strong bargaining power to the most talented persons in the relevant population. In the case of soccer, the new pay-tv technology and internet allowed not only a particular team to be watched by a global audience, but also redistributed a significant share (in Italy the largest share) of the revenues towards the most popular teams, and the most talented players. This effect has been empirically documented in other sports, as well as in cinema and music.

Evidence of superstar effects in Italian soccer has been provided by Lucifora and Simmons (Lucifora and Simmons 2003) who used data on compensation of Italian soccer players during the Championship 1995-1996, and estimated a wage equation including age, experience, and team specific variables. They found a wage premium of about 33 per cent for superstars. A more recent study of Christiansen and Sieversten ( (Christiansen and Sieversten 2008)) estimated a similar equation using 2006-2007 data and found a much stronger superstar effect, of the order of 70 per cent.

All this is common to other countries. What is specific about Italy is that, due to the documented structure of revenues, superstar costs are not sufficiently matched by commercial revenues. The strong concentration of TV rights has in the past allowed teams having superstars to partly cover these huge wage costs. Boeri and Severgnini (2008) documented that up to 2005, the distribution of TV rights was highly concentrated, Since 2006 TV rights are bargained by the Lega instead of the individual clubs and the allocation of broadcasting revenues involves some redistribution from top to lower-rank teams, that typically do not have any superstar ${ }^{6}$. Unless revenues from commercial activities and stadium attendance are significantly enhanced, even top clubs in Italy may not be in a position to afford any longer superstar costs.

\footnotetext{
${ }^{6}$ The consequences of the European Court of Justice ruling of October 4, 2011 (CGCE, cause C-403/08 and C-429/08) banning territorial borders to pay-tv operations have still to be worked out. They could further affect revenues of soccer teams.
} 


\section{The scope for greater efficiency}

Can top Italian teams succeed in reducing costs without reducing their competitive lead, at least in the national tournament? A very rough indicator of (in)efficiency is the cost per point in Serie A. This ratio is displayed in Table 1 where we take the average of the index across two subperiods: 2001-6 and 2077-11. There is a considerable variation across clubs with top teams spending significantly more per point that the other clubs. In particular, A.C. Milan, Inter, Rome, and Juventus on average, spent between 1.3 and 3.3 million euros per point in the last five years, while second layer teams (Fiorentina, Napoli, Lazio, and Udinese) spent between 0.5 and 1.5 million per point. This large difference can be partly explained by the presence of superstars in top teams.

Is it possible to improve sport performance while reducing costs? Some indication as to the scope for improvements in efficiency can be obtained by comparing the two subperiods considered in Table 1 for the same team. This points to a few success stories of clubs reducing significantly the cost per point ratio while experiencing an improvement in the sport performance. This is the case of Udinese (reducing the cost per point ratio by about 7 per cent and increasing the score by almost 10 per cent), Lazio (experiencing a similar improvement in the sport performance in spite of the more than halving the cost per point, and Atalanta (reduction of about 38 per cent in the costs per point and 15 per cent increase in the average points per Championship. Significantly, there are no success stories of this type among the top teams, where Juventus succeeded in reducing costs per point (by 13 per cent), but experienced a decline in the sport performance.

[Table 1 about here]

\section{The Ownership of the Soccer Teams and Calciopoli}

As discussed elsewhere (Boeri and Severgnini, The Italian Job: Match Rigging, Career Concerns and Media Concentration in Serie A 2008), most of the teams of Serie A are run by single entrepreneurs with other main economic interests and with some direct or indirect media influence. Most of those owners are active in oligopolistic sectors (such as TV, transportation, telecommunication, and oil refinery). This situation did not change so much in the last decade and suggests two things: first, the club is not seen as an indipendent unit whose financial sustainability should be pursued; second, the objective function is almost uniquely related to maximizing image returns. This motivation is likely to erode away as clubs are called to a major consolidation effort.

The interconnection between ownership of clubs and media played a major role in the distortions highlighligted by the Calciopoli investigation. The judicial inquiry documented, on the basis of tapped phone conversations, several episodes in which managers of Serie A teams (i.e., Juventus, A.C. Milan, Fiorentina, Lazio, and Reggina) had been bribing or exerting pressure on referees and referee designators in order to alter the outcome of crucial matches. As shown by Boeri and 
Severgnini, the match rigging method was rather efficient as it targeted career concerned referees, notably looking for promotion to the international status (Boeri og Severgnini, Match rigging and the career concerns of referees 2011)) and involved also the use of media, as indicated by the involvement in the scandal of several journalists (Boeri and Severgnini, The Italian Job: Match Rigging, Career Concerns and Media Concentration in Serie A 2008). The factors behind Calciopoli unfortunately are still there

\section{Any way out?}

Our analysis suggests that Italian football is on a unsustainable path. The problem has not been tackled so far and only very recently clubs started to reduce costs, notably wage costs, in order to reduce their debt. According to the data collected by La Gazzetta dello Sport (Laudisa 2012) the wage cost has modest cut of $0.55 \%$. However, these cost reductions are generally achieved by letting superstar players to leave and this is bound to have an impact on TV rights, by and large the main source of revenues of clubs. Due to this concentration of revenues, a consolidation made almost entirely of wage costs, inducing a decline in the international appeal of Serie A may be rather ineffective in improving the debt position of clubs. Put it another way, any serious attempt to get Italian football out of this unsustainable path, should also address the revenue side.

Why are revenues of Italian clubs so much concentrated on TV rights? A possible explanation relates to the governance structure and the ownership of clubs. Governance involves a sort of dual system in which the Federazione Italiana Giuoco Calcio (FIGC) is equally if not less powerful than the Lega di Serie A, the lobby-organisation gathering all the Presidents of Serie A teams. This distorted governance structure does not provide adequate representation of the interests of stakeholders, such as the referees, the players, and the supporters. And all the energies of the Lega's are spent in negotiations over TV rights, rather than in investing in public goods, such as campaigns promoting stadium attendance, and technologies reducing the forgery of soccer gadgets and the violation of trademarks. The ownership structure also plays an important role in the lack of diversification of revenues. Single owners can be easily blackmailed by organized groups threatening to cause, with their behavior in the stadium, fines and penalties to the team. Non-violent supporters and local communities are not involved in the ownership structure, which reduces their incentives to go to the stadiums and contribute to isolating violent groups of supporters. The experience of German clubs as well as of Barcelona and Real Madrid is quite encouraging as to the stronger motivations associated by allowing supporters to be involved in the ownership of the club.

The repression of corruption in football is also essential to restore the credibility of Serie A and increase revenues. So far, most of the attention has been devoted to changing compensation of referees, notably increasing flat rate over match-related pay. This is a positive development insofar as it reduces the possibility to exert pressure on referees via the threat of reducing the number (and type) of matches they are involved. As discussed in this chapter, match rigging often involve media pressure on referees and capture by threat rather than open bribes. In this context, the connections 
between owners of clubs and media are particularly damaging. There may be an additional case, beyond allowing for competition in the broadcasting industry, to prevent clubs to be run by owners of mass media.

Finally, a stronger involvement of pan-European governance structures could be beneficial to Italian professional football. It is the only way after all to enforce the fair play UEFA regulation. Often clubs are just too popular to fail, which makes it more difficult to restore budgetary discipline. Italy has far too many clubs. The consolidation process will unaivodably require their reduction overtime. 
Figure 1: Net (+) / losses (-) profits (in thousands of $€$ ).

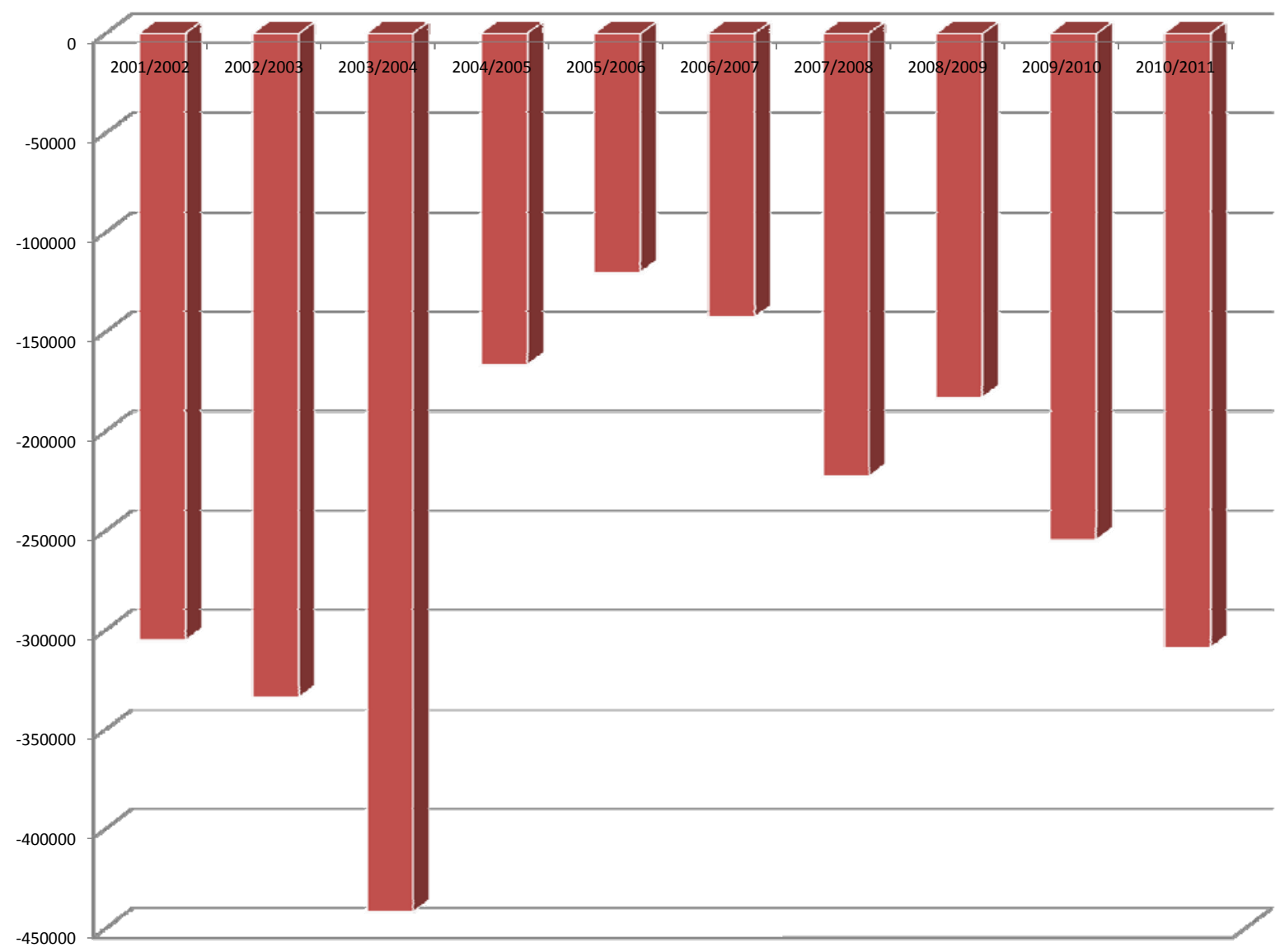

Source: Authors' elaboration using accounting data. 
Figure 2: Total Revenue of Serie $A$ teams (excluding extraordinary items) for the period 2001/2002-2010/2011

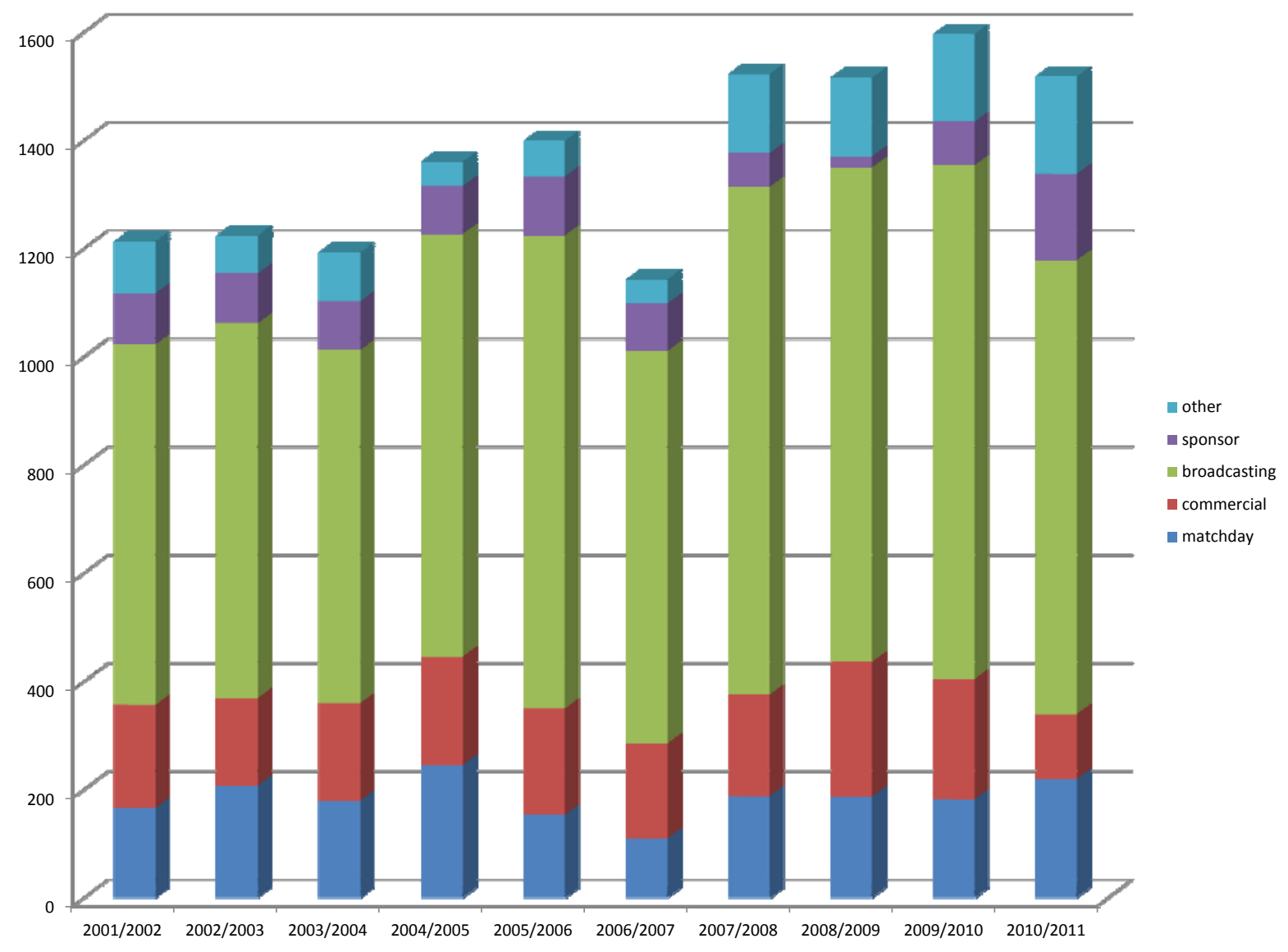

Source: PricewaterhouseCoopers 
Figure 3: Number of Spectators in Serie A in the period 2001/2002-2010/2011

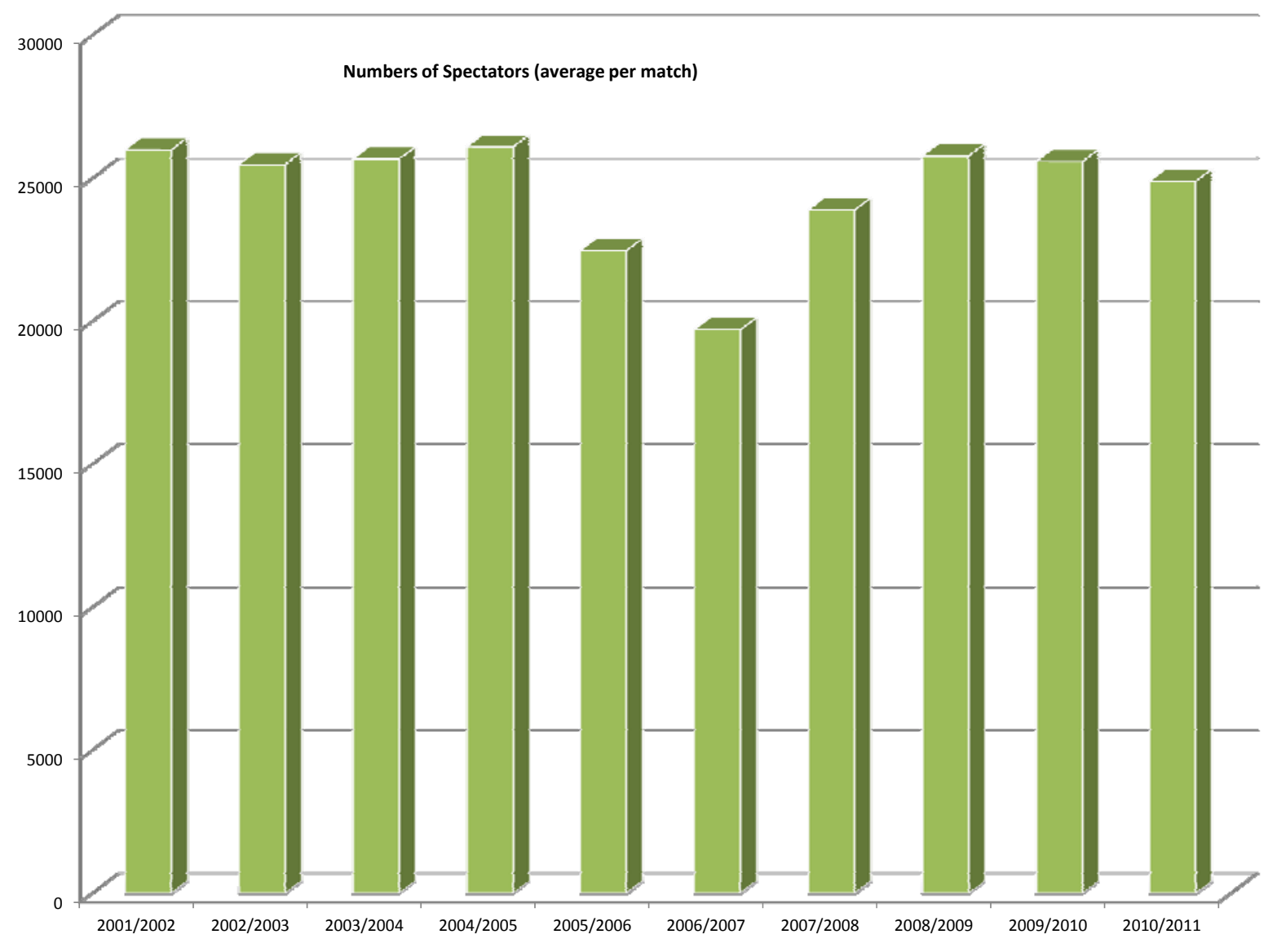

Source: Authors' calculations. 
Figure 4: Total revenues in Serie B and Lega Pro (excluding extraordinary items) in the period 2001/2002-2010/2011

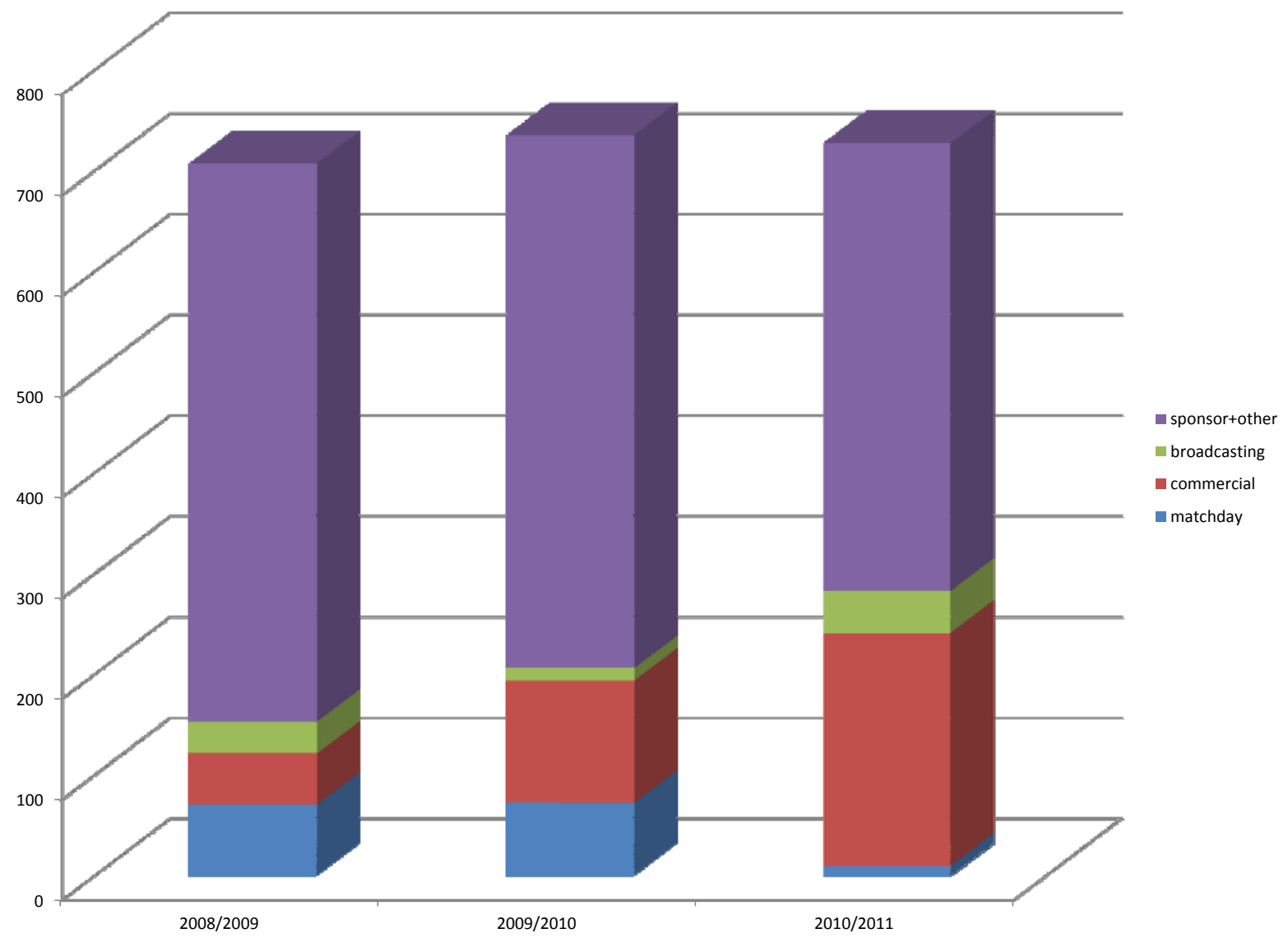

Source: PricewaterhouseCoopers. 
Figure 5: Total Revenue of the Top 20 European Teams (excluding extraordinary items) in the Championship 2010/2011

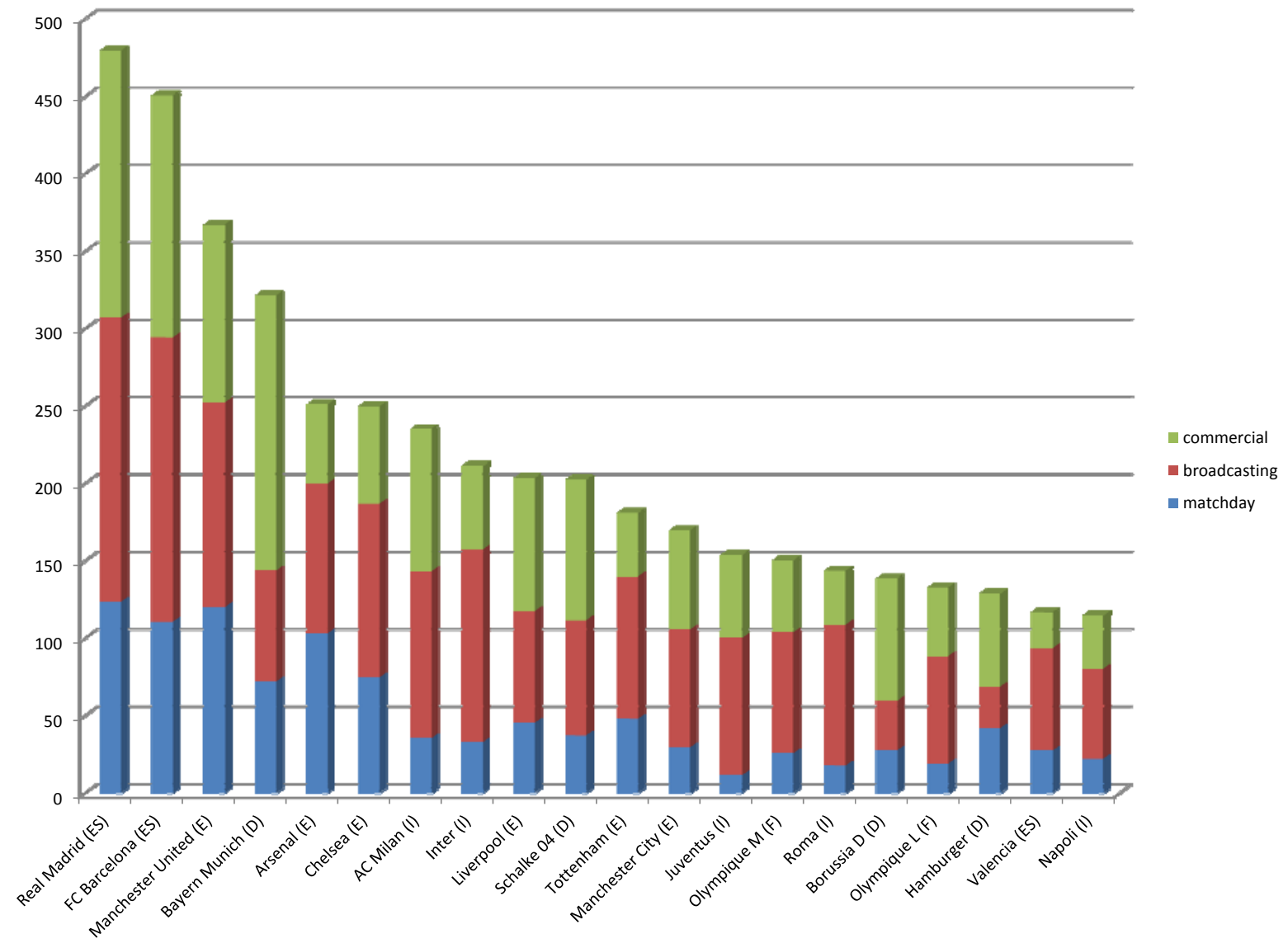

Source: Deloitte 
Figure 6: Serie A Total and Employment Costs(in thousands of $€$ )

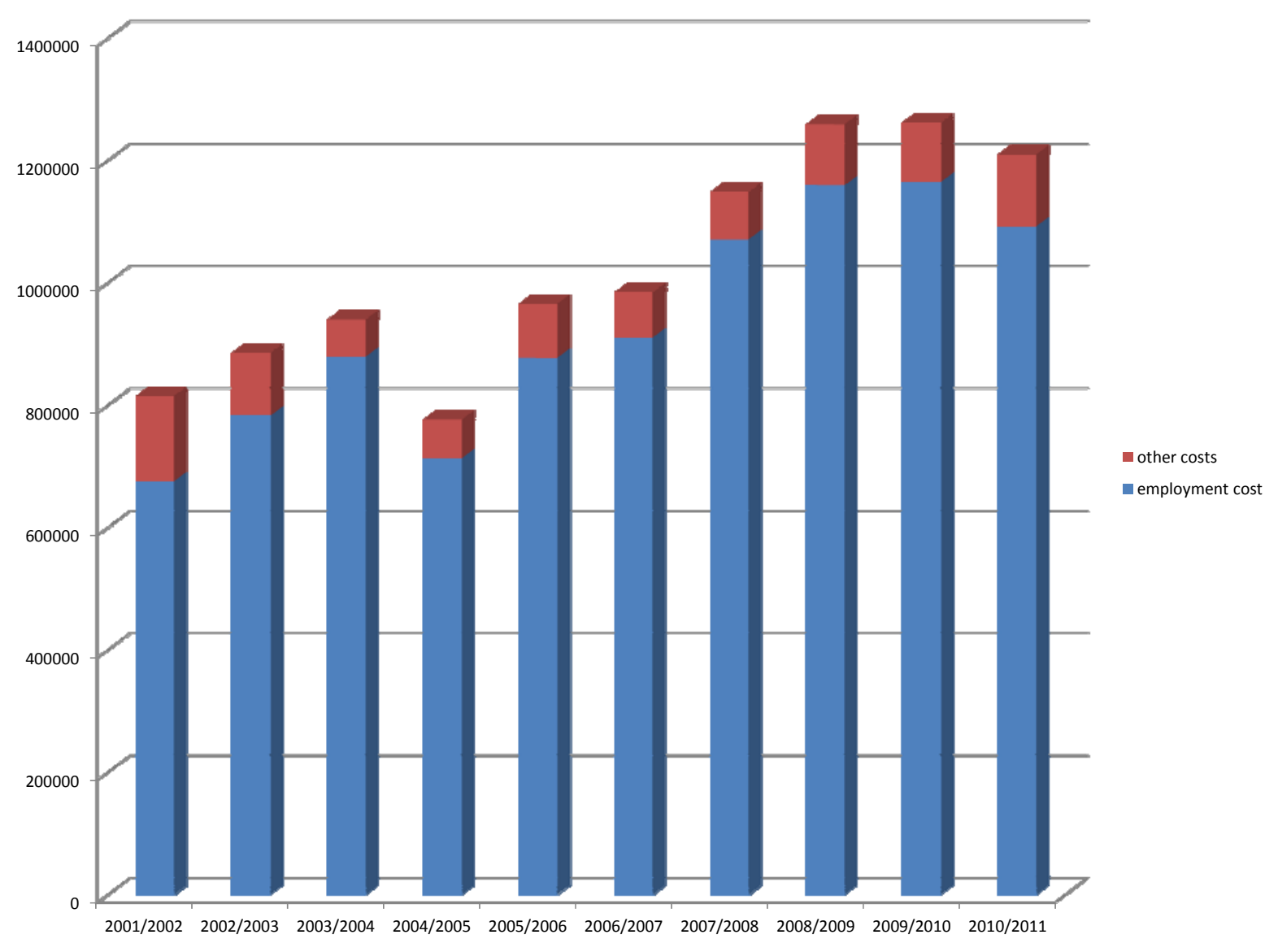

Source: Authors' calculations based on accounting data 
Table 1: Total cost (in thousands of $€$ ) per point (Source: Authors' calculations based on accounting data)

\begin{tabular}{|l|l|l|l|l|l|}
\hline \multicolumn{2}{|l|}{$\begin{array}{l}\text { Championship 2002-2006 } \\
\text { (average) }\end{array}$} & & \multicolumn{3}{l|}{$\begin{array}{l}\text { Championship 2007-2011 } \\
\text { (average) }\end{array}$} \\
\hline Team & Cost per point & Points & team & Cost per point & Points \\
\hline Juventus & 1.822 & 78 & Inter & 2.363 & 85 \\
\hline Inter & 2.288 & 68 & Roma & 1.350 & 73 \\
\hline Milan & 3.180 & 67 & Milan & 3.354 & 70 \\
\hline Roma & 1.262 & 61 & Juventus & 1.584 & 65 \\
\hline Palermo & 569 & 53 & Fiorentina & 992 & 58 \\
\hline Chievo & 413 & 50 & Palermo & 667 & 57 \\
\hline Udinese & 617 & 50 & Lazio & 613 & 54 \\
\hline Lazio & 1.503 & 49 & Udinese & 575 & 54 \\
\hline Parma & 622 & 49 & Sampdoria & 696 & 52 \\
\hline Sampdoria & 596 & 49 & Atalanta & 390 & 45 \\
\hline Livorno & 292 & 47 & Empoli & 370 & 45 \\
\hline Bologna & 696 & 43 & Parma & 749 & 44 \\
\hline Reggina & 414 & 40 & Chievo & 505 & 42 \\
\hline Atalanta & 635 & 39 & Bologna & 816 & 40 \\
\hline Siena & 597 & 39 & Siena & 652 & 40 \\
\hline Empoli & 368 & 38 & Reggina & 442 & 37 \\
\hline Fiorentina & 987 & 36 & Lecce & 656 & 36 \\
\hline Lecce & 582 & 36 & Livorno & 414 & 34 \\
\hline
\end{tabular}




\section{References}

AREL, PricewaterhouseCoopers and Federcalcio. ReportCalcio. Rome: AREL, 2012.

Babatunde, Buraimo, Giuseppe Migali, and Robert Simmons. Corruption does not pay: An analysis of consumer response to Italy's Calciopoli Scandal. Lancaster: Lancaster University Working Paper, 2012.

Baroncelli, Alessandor, and Umberto Lago. "Italian Football." Journal of Sport Economics, February 2006: 13-28.

Bianchi, Luigi Arturo, andDiego Corrado. I bilanci delle società di calcio - Le ragioni di una crisi. Milan: Egea, 2004.

Boeri, Tito, and Battista Severgnini. "Calciopoli anno zero." In II management del calcio. La partita più lunga, by Francesco Bof, Fabrizio Montanari and Giacomo Silvestri, 63-74. Milan: Franco Angeli, 2008.

Boeri, Tito, and Battista Severgnini. The Italian Job: Match Rigging, Career Concerns and Media Concentration in Serie A. Bonn: IZA Discussion Paper, 2008.

Boeri, Tito, and Battista Severgnini. "Match rigging and the career concerns of referees. "Labour Economics 18, nr. 3 (2011): 349-359.

Christiansen, Nikolai Allan, and Hans Henrik Sieversten. "The Explotation of Talent." Nationaløkonomisk Tidsskrift, 2008: 319-326.

Deloitte LLP. Fan Power. Foootball Money League. London: Deloitte, 2012.

Dobson, Stephen, and John Goddard. The Economics of Professional Football. 2nd. Cambridge: Cambridge University Press, 2011.

Dragoni, Gianni. "Le big in profondo rosso." I/ Sole 24 Ore, May 29, 2012: 1-3.

Iaria, Marco. „Conti di A: sempre peggio. Le spese piu' su dei ricavi."La Gazzetta Dello Sport, 9. March 2012.

ISTAT. »Indice ISTAT dei prezzi al consumo.« ISTAT, 2012.

Istat. Lo Sport che Cambia. Argomenti, Rome: Istituto nazionale di Statistica, 2005.

Lago, Umberto. "The State of Italian Footbal Industry." In Handbook on the Economics of Sport, edited by Wladimir Andreff, Szymański and Stefan, 463-473. Chelthenam: Edward Elgar, 2006.

Laudisa, Carlo "Stipendi: La dieta c'e', ma non si vede",La Gazzetta dello Sport, September 11, 2012, 1. 
Lucifora, Claudio, and Robert Simmons. "Superstar Effects in Sports: Evidence from Italian Soccer." Journal of Sport Economics, 2003: 35-55.

Malaguti, Vittorio. I conti truccati del calcio.Perche' il mondo del pallone e' sull'orlo del fallimento. Rome: Carocci, 2002.

Masucci, Roberto, and Nicola Gallo. La sicurezza negli stadi. Milan: Fraco Angeli, 2012.

Mediobanca, Ufficio Studi. Le principali societa' italiane. Milan: Mediobanca, 2011.

Ministero dell'Interno. »Osservatorio Nazionale sulle Manifestazioni Sportive, 2007-2008.« Rome, 2008.

Rosen, Sherwin. »The Economics of Superstar. " American Economic review, 1981: 845-858.

Rosen, Sherwin, and Allen Sanderson. "Labour Markets in Professional Sports." Economic Journal, 2001: F47-68.

UEFA. UEFA Club Licensing and the Financial Fair Play Regulation. Nyon: UEFA, 2010. 